\title{
Risk factors associated with Diabetes Mellitus in COVID-19 infected patients: A meta-analytic synthesis of observational studies
}

\author{
Upasna Gaba ${ }^{1}$, Mohammad Altamish ${ }^{2}$, Md Azharuddin ${ }^{3}$, Mohammad Adil ${ }^{3}$, Pinaki \\ Ghosh $^{4}$, Bishal Gyawali ${ }^{5}$, and Manju Sharma ${ }^{6}$ \\ ${ }^{1}$ Manipal Academy of Higher Education \\ ${ }^{2}$ School of Pharmaceutical Education and Research, Jamia Hamdard, \\ ${ }^{3}$ School of Pharmaceutical Education and Research, Jamia Hamdard \\ ${ }^{4}$ Bharati Vidyapeeth Deemed University Poona College of Pharmacy \\ ${ }^{5}$ Global Health Section, University of Copenhagen \\ ${ }^{6}$ Jamia Hamdard
}

March 27, 2021

\begin{abstract}
Aims: We carried out a systematic literature review and meta-analytic synthesis to find out association between DM and related outcomes in patients with COVID-19 infection. Methods: We systematically searched MEDLINE, and Web of Science to identify studies investigating comorbidities, clinical manifestations and resource utilization of diabetic patients exposed with COVID-19 published from inception to January 2021. Meta-analysis was carried out using Review Manager 5.3. Random effects model was used to compute the pooled estimates of odds ratio/mean difference (OR)/(MD) and $95 \%$ confidence intervals (CI). Results: Results from the pooled meta-analysis found that CVD, hypertension, AKI, cerebrovascular disease, AKI and ARDS were significantly associated with DM in COVID-19 infected patients compared to non-diabetic patients. There is significant association found between mortality and DM compared to non-diabetic patients [OR (95\% CI): 2.46 (1.68, 3.58)]. ICU admission and use of mechanical ventilation was significantly associated with DM and COVID-19 vs. non-diabetic [OR (95\% CI): $2.79(1.79,4.34)$ and $3.33(2.05,5.42)]$ respectively. However, LOS, hospitalization, and ICU admission were not significantly differing between diabetes vs. non-diabetes. Conclusions: The results showed a significant association between mortality and DM exposed with COVID-19. Other co-morbidities especially CVD/hypertension could be a serious threat for DM COVID-19 infected patients for the higher mortality.
\end{abstract}

\section{Introduction}

Coronavirus disease 2019 (COVID-19) is caused by severe acute respiratory syndrome coronavirus 2 (SARSCoV-2, earlier known as 2019-nCoV) (1). The outbreak of COVID-19 rapidly caused a global health crisis (2), (3) and the World Health Organization has announced COVID-19 as a pandemic.

Diabetes mellitus (DM) is one of the most frequent comorbidities reported in patients infected with COVID19. The inflammatory process associated with DM and chronic high levels of glucose in the blood can lead to low immunity response which aggravate infections in diabetic patients (4). There are several evidences of increased incidence and severity of COVID-19 in patients with DM reported with higher risk for intensive care unit (ICU) admission and substantial mortality (5). In addition, obesity has been associated with disease severity and guidelines recommend that obese patients especially those with severe obesity should take extra measures to avoid COVID-19 infection (6). It has been reported that compared with non-ICU patients, ICU patients have a higher proportion of diabetes. Additionally, it is also suggested that DM may affect the clinical manifestations and patient's disease progression (7). 
A recent retrospective study suggested that Type $2 \mathrm{DM}$ and obesity may have contributed to disease severity and mortality in COVID-19 critically ill patients (8). Another retrospective cross-sectional study conducted in United Kingdom reported that hospitalized COVID-19 patients with DM had longer LOS in hospital than patients without DM. Same study also documented that elder COVID-19 patients with DM and patients without diabetic ketoacidosis were less likely to survive compared to younger patients and patients with diabetic ketoacidosis, respectively (9). Similar to these findings, another cohort study conducted in China, retrospectively reviewed 258 consecutive hospitalized COVID-19 patients with or without DM suggested that DM is associated with increased disease severity and a higher risk of mortality in patients infected with COVID-19. In addition, impaired fasting glucose and diabetes at admission were significantly associated with higher risks of adverse outcomes among COVID-19 infected patients (10). Few observational studies suggested that diabetes was significantly associated with higher risks of composite adverse endpoints (death, ICU admission, and mechanical ventilation) (10).

The increased rate of those suffering from diabetes combined with the prevalence of COVID-19 suggest that the care for diabetic patients must be increased in order to reduce any further complications and the risk of death. The poor outcomes of patients with diabetes and COVID-19 indicated that more supervision is required in these patients. Hence with the high global burden of diabetes and the increasing number of COVID-19 cases, there is a need to understand the association of diabetes and COVID-19 related outcomes in COVID-19 infected patients.

To date no meta-analysis conducted to explore possible risk factors and resource utilization in DM patients infected with in COVID-19. Therefore, we aimed to conduct a meta-analysis to find out association between DM and poor outcomes in patients with COVID-19 infection.

\section{Materials and methods}

This systematic literature review and meta-analysis was performed in accordance with the Preferred Reporting Items for Systematic Reviews and Meta-analyses (PRISMA) statement (11) and it was prospectively registered on Prospective Register of Systematic Reviews (PROSPERO) (CRD42020213791).

\section{Data sources and search strategy}

Databases, the Medical Literature Analysis and Retrieval System Online (MEDLINE)/PubMed, and Web of Science were searched using a comprehensive search strategy to identify eligible studies published in the English language from inception to January 2021. Search terms used were "diabetes mellitus", "diabetes", "Coronavirus", "COVID-19", and "SARS-CoV-2. Additionally, manual searches were performed on Google Scholar and bibliographies of relevant articles and previous systematic review (12) were also screened to identify other significant studies.

\section{Study selection and data extraction}

Two reviewers independently performed the selection of study based on an initial screening of identified titles and abstracts followed by second screening of full-text articles. Studies were considered eligible if they met the following criteria: (i) studied subjects were diabetic and non-diabetic exposed with COVID-19; (ii) outcome of interest reported comorbidities, clinical manifestations of COVID-19; (iii) studies using observational study design (retrospective cohort, case-control, prospective cohort, and cross-sectional studies).

Two independent authors performed study screening and data extraction judiciously according to inclusion criteria. Any discrepancies were resolved through discussion of the third author until consent was achieved. A standard data extraction format was used to capture the study information, including name of the first author, year of the publication, country, study design, age, gender, settings, country, database used, study population, no. of comorbidities/symptoms reported, and other relevant information. 


\section{Quality assessment}

Two authors independently assessed the quality of the methodology for each study using the NewcastleOttawa scale (NOS) (13). The NOS comprised of three scales; selection (maximum of four stars), comparability (maximum of two stars), exposure/outcome (maximum of three stars) and graded out of 9 points (stars). This assessment critically appraised the internal (systematic error) and external validity of the studies. We consider studies with a score of 6 or greater as high quality. Any disagreement was resolved through consensus.

\section{Data analysis}

We carried out meta-analysis to calculate the pooled estimates of odds ratio/mean difference (OR)/(MD) and $95 \%$ confidence intervals (CI). Random effects model (DerSimonian and Laird) was used for the overall pooled estimate meta-analysis.

To provide a quantitative estimate of the association of the symptoms/complication of interest with severity outcomes (ICU admission, length of stay (LOS) or need for mechanical ventilation) or deaths were calculated from crude frequency of exposed and non-exposed cases.

Heterogeneity among studies was assessed with the Cochran chi-square $\left(\chi^{2}\right)$ and quantified with the $\mathrm{I}^{2}$ and tau-square $\left(?^{2}\right)$. Statistical heterogeneity was reported using the $\mathrm{I}^{2}$ statistic, with results ranging from 0 to $100 \%$ and values of 25,50 and $75 \%$ representing low, moderate and high level of heterogeneity, respectively. All the statistical analysis was conducted using Review Manager 5.3 (Nordic Cochrane Centre, Cochrane Collaboration, 2014). A p values of $<0.05$ was considered statistically significant.

\section{Results}

\section{Literature search and study inclusion}

The PRISMA flow diagram summarizing the process of study selection is shown in Figure 1. The electronic search identified 1237 potentially relevant records, of which 1100 were excluded after screening the title and abstract. The remaining 61 full-text articles were assessed for eligibility and 47 were further excluded due no information on COVID-19 infected non diabetes patients, mortality, resource utilization, and study design. Total 14 articles were included for the systematic review and meta-analysis.

\section{Study characteristics and quality assessment}

Of 14 included observational studies, all studies were retrospective. The general characteristics of included studies are reported in Table 1. Among included 14 studies, 12 were conducted in China, 1 in USA, and 1 in England. This meta-analysis involved 5697 patients (diabetic $=1428$ and non-diabetic $=3644$ ).

The quality assessment of the included studies is shown in supplementary Table S1. The NOS results showed that the average score was 7.2 (range 6-9) for all included studies. Therefore, the quality of included studies suggested good (14).

\section{Symptoms associated with DM and COVID-19 infection}

Out of 14 included studies, total 11 studies reported symptoms including fatigue, fever, headache, myalgia, nausea/vomiting, anorexia, cough, diarrhoea, dyspnoea, palpitation, pharyngalgia, shortness of breath, polypnea, sore throat, sputum, chest pain and expectoration. Fever and cough followed by fatigue and diarrhoea were most commonly reported symptoms across the included studies.

Results from the pooled meta-analysis found non-significant symptoms trends in DM patients infected with COVID-19 compared to non-diabetic COVID-19 patients infected. However, dyspnoea was significantly 
association with DM $\left[2.30(1.37,3.84)\right.$; p value $=0.001 ; I^{2}=72 \%$; p value $\left.=0.003\right]$ compared with non-diabetic patients infected with COVID-19 (Table 2).

\section{Comorbidity associated with DM and COVID-19 infection}

Total 11 studies reported comorbidities/complications including hypertension, CLD, COPD, thyroid disease, AKI, cancer, cerebrovascular disease, CKD, digestive disease, septic shock, and AKI. COPD, CVD, and hypertension followed by cerebrovascular disease, cancer and CKD were most commonly reported comorbidities/complications across the included studies.

From reported co-morbidities, CVD, hypertension, AKI, cerebrovascular disease, AKI and ARDS were significantly associated with DM in COVID-19 infected patients compared to non-diabetic patients (2.91 [2.34, $3.63], \mathrm{p}<0.00001 ; 2.19[1.39,3.46], \mathrm{p}=0.0008 ; 3.59$ [1.46, 8.84], $\mathrm{p}=0.005 ; 2.09$ [1.22, 3.61], $\mathrm{p}=0.008$; and 3.01 $[1.63,5.58], \mathrm{p}=0.0005$; and $3.40[2.09,5.55], \mathrm{p}<0.00001$; respectively). However, no significant association was observed with CLD, COPD, thyroid disease, cancer, CKD, digestive disease, and septic shock in DM patients infected with COVID-19 compared to non-diabetic patients (Figure 2. and supplementary Table S2).

\section{Diabetes and outcome}

It includes mortality, recovery, length of stay (LOS), mechanical ventilation, need for ICU, discharge from hospital, and hospitalization (Figure 3. and supplementary Table S3).

\section{Association between mortality/recovery and DM in COVID-19 infected patients}

Total 12 and 5 studies reported outcome as mortality and recovery respectively. Pooled results from metaanalysis found significant association between mortality and DM compared to non-diabetic patients infected with COVID-19 (2.46 [1.68, 3.58], $\left.\mathrm{p}<0.00001 ; I^{2}: 62 \% ; \mathrm{p}=0.002\right)$. However, no significant association was found between recovery with DM compared to non-diabetic COVID-19 infected patients $(0.48$ [0.21, 1.07], $\left.\mathrm{p}=0.07 ; I^{2}: 85 \% ; \mathrm{p}<0.00001\right)$ (Figure 3$)$.

\section{Association between healthcare utilization and DM in COVID-19 infected pa- tients}

LOS and hospitalization were not significantly differing between diabetes and non-diabetes patients infected with COVID-19 (1.91 [-1.12, 4.94], $\mathrm{p}=0.22 ; \mathrm{I}^{2}: 91 \%, \mathrm{p}<0.00001$ and $1.45[0.51,4.08], \mathrm{p}=0.49 ; \mathrm{I}^{2}: 59 \%$, $\mathrm{p}=0.12$ respectively) (Figure 4). However, discharge from hospital was significantly higher in non-diabetic patients infected with COVID-19 compared to diabetic patients $\left(0.52[0.34,0.81], \mathrm{p}=0.004 ; \mathrm{I}^{2}: 6 \%, \mathrm{p}=0.35\right)$. On the other hand, ICU admission and use of mechanical ventilation was significantly associated with DM and COVID-19 infected patients compared to non-diabetic patients $\left(2.79[1.79,4.34], \mathrm{p}<0.00001 ; \mathrm{I}^{2}: 0 \%\right.$, $\mathrm{p}=0.53$ and $3.33[2.05,5.42], \mathrm{p}<0.00001 ; \mathrm{I}^{2}: 48 \%, \mathrm{P}=0.09$, respectively) (Figure 3 ).

\section{Discussion}

This systematic review and meta-analysis of 14 studies aimed to evaluate the association between DM and COVID-19 infected patients. Results from current study showed that mortality, ICU, ARDS, mechanical ventilation, discharge from hospital, hospitalization and co-morbidities (CVD, hypertension, AKI, cerebrovascular disease, acute cardiac injury) are significantly associated with DM in COVID-19 infected patients. 
Diabetes is one of the most frequent comorbidities reported in patients with COVID-19. The prevalence of diabetes among patients with COVID-19 varied in different studies. Studies in Chinese patients reported prevalence rates ranged from 5.3 to $8.2 \%$ (3-5), while a recent study involved 5,700 patients reported that $33.8 \%$ had diabetes (6). Several studies have reported that diabetes and uncontrolled glycemia were significant predictors of severity and mortality in patients infected with lower respiratory tract infections (10).

Previous studies found increased severity of COVID-19, caused by infection with SARS-CoV-2 in patients with DM. Interacting with other risk factors; hyperglycaemia might modulate immune and inflammatory responses, thus predisposing patients to severe COVID-19 and possible lethal outcomes. Potential pathogenetic links between COVID-19 and DM include effects on glucose homeostasis, inflammation, altered immune status and activation of the renin-angiotensin-aldosterone system (15).

Presence of DM and the individual degree of hyperglycaemia seem to be independently associated with COVID-19 severity and increased mortality $(12,16)$. Furthermore, the presence of typical complications of DM (CVD, heart failure and CKD) also increases COVID-19 mortality (11,19). In current meta-analysis we found higher mortality rate in DM COVID-19 infected patients compared to non-DM COVID-19 infected patients.

COVID-19 can progress to ARDS, which requires positive pressure oxygen and intensive care therapy (9). Previous systematic review and meta-analysis conducted by Huang et al. (2020) (17) showed that ARDS and disease progression was significantly associated with DM in COVID-19 infected patients. In addition, a retrospective case study conducted by Chen et al. (2020) reported that SARS-CoV-2 can cause both pulmonary and systemic inflammation, leading to multi-organ dysfunction in patients at high risk (18). ARDS, respiratory failure, sepsis, acute cardiac injury, and heart failure were the most common critical complications during exacerbation of COVID-19 (18). In line with previous finding, our meta-analysis also found significant association between DM and ARDS and other co-morbidities in COVID-19 infected patients compared to non-DM COVID-19 infected patients. In addition, various studies reported that patients with diabetes are more likely than healthy people to develop COVID-19 disease and complications such as ARDS and even death (19-22).

Study reported the overall symptoms of COVID-19 in all patients are sore throat, fever, dry cough, fatigue, and diarrhoea $(23,24)$. To support our findings, international diabetes federation (IDF) statement reported that symptoms in diabetes patients not different with other COVID-19 patients (25). But there is an agreement that symptoms are more developed among diabetic patients $(26,27)$.

Another study conducted in Greece reported that Type 2 diabetes and obesity may have contributed to disease severity and mortality in COVID-19 critically ill patients (8). HbA1c is associated with inflammation, hypercoagulability, and low SaO2 in COVID-19 patients, and the mortality rate (27\%) is higher in DM patients (28).

In a case-report on a patient with both COVID-19 and diabetes, the patient was discharged from the hospital after 15 days. The survival term of the non-survivors is likely to be within 1-2 weeks after ICU admission. The severity of SARS-CoV-2 pneumonia poses great strain to hospital critical care resources, especially if they are not adequately staffed or resourced (29). In a retrospective cohort of 312 patients with COVID-19, we found that diabetes was associated with higher risks of composite adverse endpoints (mechanical ventilation, admission to ICU, or death) and mortality, and IFG was also associated with higher risk of mortality. Similarly, in the current meta-analysis we also observed that ICU admission, mechanical ventilation, discharge from hospital and hospitalizations are significantly associated with DM COVID-19 infected patients compared to non-DM COVID-19 infected patients. This finding could be a potential outcome to support development of health economics model for the use of diabetic medication in DM COVID-19 infected patients and help decision making process.

Association between DM and COVID-19 was also explored in the previous published systematic review and meta-analysis, but these studies considered limited studies and low sample size (references). Interestingly, no studies yet compared DM COVID-19 infected patients and non-DM COVID-19 infected patients. To 
best of our knowledge this is the only largest meta-analysis to evaluate risk factors and resource utilization associated with DM COVID-19 infected patients compared to non-DM COVID-19 infected patients.

\section{Implication and recommendation:}

This meta-analysis suggests a strong association between risk factors (mortality and co-morbidities) with DM COVID-19 infected patients. To reduce risk of disease progression, preventive measures should be considered by DM patients. Proper management of blood glucose level during COVID-19 pandemic might help DM patients to avoid humanistic and economic burden which may arises due to ICU admission, frequent hospital visits, hospitalization and mechanical ventilation requirement.

\section{Conclusion}

This meta-analysis of observational study showed a significant association between mortality and DM COVID-19 infected patients. Other co-morbidities especially CVD/hypertension could be a serious threat for DM COVID-19 infected patients for the higher mortality. Further long term, multinational and large sample size clinical studies warranted to justify current findings.

\section{Conflict of interest}

The authors declare no conflict of interests associated with this publication.

\section{Acknowledgements}

This research did not receive any specific grant from funding agencies in the public, commercial, or not-forprofit sectors.

\section{Ethical approval}

This article does not contain any studies with human participants or animals performed by any of the authors.

\section{References}

1. Zhu N, Zhang D, Wang W, Li X, Yang B, Song J, et al. A novel coronavirus from patients with pneumonia in China, 2019. New England journal of medicine. 2020.

2. Liu Y, Lee JM, Lee C. The challenges and opportunities of a global health crisis: the management and business implications of COVID-19 from an Asian perspective. Asian Business \& Management. 2020;19:27797.

3. Huang AT, Garcia-Carreras B, Hitchings MD, Yang B, Katzelnick LC, Rattigan SM, et al. A systematic review of antibody mediated immunity to coronaviruses: antibody kinetics, correlates of protection, and association of antibody responses with severity of disease. MedRxiv. 2020.

4. Iacobellis G. COVID-19 and diabetes: Can DPP4 inhibition play a role? Diabetes research and clinical practice. 2020;162.

5. Roncon L, Zuin M, Rigatelli G, Zuliani G. Diabetic patients with COVID-19 infection are at higher risk of ICU admission and poor short-term outcome. Journal of Clinical Virology. 2020;127:104354.

6. Malavazos AE, Corsi Romanelli MM, Bandera F, Iacobellis G. Targeting the adipose tissue in COVID-19. Obesity. 2020;28(7):1178-9.

7. Wang F, Qu M, Zhou X, Zhao K, Lai C, Tang Q, et al. The timeline and risk factors of clinical progression of COVID-19 in Shenzhen, China. Journal of Translational Medicine. 2020;18(1):1-11.

8. Halvatsiotis P, Kotanidou A, Tzannis K, Jahaj E, Magira E, Theodorakopoulou M, et al. Demographic and clinical features of critically ill patients with COVID-19 in Greece: The burden of diabetes and obesity. Diabetes research and clinical practice. 2020;166:108331. 
9. Alkundi A, Mahmoud I, Musa A, Naveed S, Alshawaf M. Clinical characteristics and outcomes of COVID19 hospitalized patients with diabetes in UK: A retrospective single centre study. Diabetes Research and Clinical Practice. 2020.

10. Zhang J, Kong W, Xia P, Xu Y, Li L, Li Q, et al. Impaired fasting glucose and diabetes are related to higher risks of complications and mortality among patients with coronavirus disease 2019. Frontiers in endocrinology. 2020;11:525.

11. Moher D, Liberati A, Tetzlaff J, Altman DG, Group P. Preferred reporting items for systematic reviews and meta-analyses: the PRISMA statement. PLoS medicine. 2009;6(7):e1000097.

12. de Almeida-Pititto B, Dualib PM, Zajdenverg L, Dantas JR, De Souza FD, Rodacki M, et al. Severity and mortality of COVID 19 in patients with diabetes, hypertension and cardiovascular disease: a meta-analysis. Diabetology \& metabolic syndrome. 2020;12(1):1-12.

13. Wells GA, Shea B, O'Connell Da, Peterson J, Welch V, Losos M, et al. The Newcastle-Ottawa Scale (NOS) for assessing the quality of nonrandomised studies in meta-analyses. Oxford; 2000.

14. Azharuddin M, Adil M, Sharma M, Gyawali B. A systematic review and meta-analysis of non-adherence to anti-diabetic medication: Evidence from low-and middle-income countries. Authorea Preprints. 2021.

15. Lim S, Bae JH, Kwon H-S, Nauck MA. COVID-19 and diabetes mellitus: from pathophysiology to clinical management. Nature Reviews Endocrinology. 2020:1-20.

16. Holman N, Knighton P, Kar P, O'Keefe J, Curley M, Weaver A, et al. Risk factors for COVID-19-related mortality in people with type 1 and type 2 diabetes in England: a population-based cohort study. The lancet Diabetes \& endocrinology. 2020;8(10):823-33.

17. Huang I, Lim MA, Pranata R. Diabetes mellitus is associated with increased mortality and severity of disease in COVID-19 pneumonia-a systematic review, meta-analysis, and meta-regression. Diabetes \& Metabolic Syndrome: Clinical Research \& Reviews. 2020;14(4):395-403.

18. Chen T, Wu D, Chen H, Yan W, Yang D, Chen G, et al. Clinical characteristics of 113 deceased patients with coronavirus disease 2019: retrospective study. bmj. 2020;368.

19. Apicella M, Campopiano MC, Mantuano M, Mazoni L, Coppelli A, Del Prato S. COVID-19 in people with diabetes: understanding the reasons for worse outcomes. The lancet Diabetes \& endocrinology. 2020.

20. Sanyaolu A, Okorie C, Marinkovic A, Patidar R, Younis K, Desai P, et al. Comorbidity and its Impact on Patients with COVID-19. SN comprehensive clinical medicine. 2020:1-8.

21. Lei M, Lin K, Pi Y, Huang X, Fan L, Huang J, et al. Clinical Features and Risk Factors of ICU Admission for COVID-19 Patients with Diabetes. Journal of diabetes research. 2020;2020.

22. Wu C, Chen X, Cai Y, Zhou X, Xu S, Huang H, et al. Risk factors associated with acute respiratory distress syndrome and death in patients with coronavirus disease 2019 pneumonia in Wuhan, China. JAMA internal medicine. 2020;180(7):934-43.

23. Ata F, Almasri H, Sajid J, Yousaf Z. COVID-19 presenting with diarrhoea and hyponatraemia. BMJ Case Reports CP. 2020;13(6):e235456.

24. Qiu H, Wu J, Hong L, Luo Y, Song Q, Chen D. Clinical and epidemiological features of 36 children with coronavirus disease 2019 (COVID-19) in Zhejiang, China: an observational cohort study. The Lancet Infectious Diseases. 2020;20(6):689-96.

25. Belkhadir J. COVID-19 and diabetes from IDF MENA region. diabetes research and clinical practice. 2020;166:108277.

26. Li G, Deng Q, Feng J, Li F, Xiong N, He Q. Clinical characteristics of diabetic patients with COVID-19. Journal of diabetes research. 2020;2020. 
27. Abdi A, Jalilian M, Sarbarzeh PA, Vlaisavljevic Z. Diabetes and COVID-19: A systematic review on the current evidences. Diabetes research and clinical practice. 2020;166:108347.

28. Wang Z, Du Z, Zhu F. Glycosylated hemoglobin is associated with systemic inflammation, hypercoagulability, and prognosis of COVID-19 patients. Diabetes research and clinical practice. 2020;164:108214.

29. Yang X, Yu Y, Xu J, Shu H, Liu H, Wu Y, et al. Clinical course and outcomes of critically ill patients with SARS-CoV-2 pneumonia in Wuhan, China: a single-centered, retrospective, observational study. The Lancet Respiratory Medicine. 2020;8(5):475-81.

\section{Figure legends}

Figure 1. PRISMA flow diagram of study selection process

Figure 2. Forest plot for comorbidities associated with diabetes vs. non-diabetic exposed with COVID-19

Blue squares and horizontal lines represent study-specific estimates and 95\% CI. The size of the square is proportional to the weights of the individual studies. Black diamond represents pooled estimates (center) and $95 \%$ CI (width).

Figure 2.1: Chronic kidney disease (CKD);2.2: Chronic liver disease (CLD); 2.3: Acute respiratory distress syndrome (ARDS); 2.4: Cardiovascular disease (CVD) 2.5: Chronic obstructive pulmonary disease (COPD); 2.6: Thyroid disease; 2.7: Acute kidney injury (AKI); 2.8: Hypertension; 2.9: Cerebrovascular Diseases; 2.10: Acute Cardiac Injury; 2.11: Digestive disease; 2.12: Cancer; 2.13: Septic Shock

Figure 3. Forest plot for diabetes associated outcomes vs. non-diabetic exposed with COVID-19

Blue squares and horizontal lines represent study-specific estimates and $95 \%$ CI. The size of the square is proportional to the weights of the individual studies. Black diamond represents pooled estimates (center) and $95 \%$ CI (width).

Outcomes comprised of; Mortality, Recovered, Hospitalization, Mechanical ventilation, ICU (Intensive care unit) admission, length of stay (LOS), Discharge from hospital

Figure 3.1: Mortality; 3.2: Recovered;3.3: Length of stay (LOS); 3.4: Mechanical ventilation; 3.5: ICU (Intensive care unit) admission;3.6: Discharge from hospital; 3.7: Hospitalization

Table 1. Characteristics of included studies 


\begin{tabular}{|c|c|c|c|c|c|c|c|c|}
\hline $\begin{array}{l}\text { Author, } \\
\text { Year }\end{array}$ & Country & $\begin{array}{l}\text { Study } \\
\text { design }\end{array}$ & $\begin{array}{l}\text { Sample } \\
\text { size }(N)\end{array}$ & $\begin{array}{l}\text { Diabetes } \\
\text { diabetes }\end{array}$ & $\begin{array}{l}\text { Jon- } \\
\text { Age }\end{array}$ & $\begin{array}{l}\text { Comorbid } \\
\text { Compli- } \\
\text { cations }\end{array}$ & $\begin{array}{l}\text { ties / } \\
\text { Symptoms }\end{array}$ & $\begin{array}{l}\text { Mortality, } \\
\text { Alive/recov }\end{array}$ \\
\hline $\begin{array}{l}\text { Zhang, } \\
2020\end{array}$ & China & $\begin{array}{l}\text { Retrosp } \\
\text { Cohort } \\
\text { Study }\end{array}$ & e258 & $63 / 195$ & $\begin{array}{l}\text { Median } \\
\text { (IQR): } 64 \\
(56-70)\end{array}$ & $\begin{array}{l}\text { Hypertensi } \\
\text { Cardiovas- } \\
\text { cular } \\
\text { disease } \\
\text { (CVD), } \\
\text { Cere- } \\
\text { brovascu- } \\
\text { lar } \\
\text { disease, } \\
\text { Chronic } \\
\text { obstruc- } \\
\text { tive } \\
\text { pulmonary } \\
\text { dis- } \\
\text { ease(COPD } \\
\text { Chronic } \\
\text { kidney dis- } \\
\text { ease(CKD) } \\
\text { Chronic } \\
\text { liver dis- } \\
\text { ease(CLD), } \\
\text { Can- } \\
\text { cer/Malign } \\
\text { Acute } \\
\text { cardiac in- } \\
\text { jury(ACI), } \\
\text { Acute res- } \\
\text { piratory } \\
\text { distress } \\
\text { syn- } \\
\text { drome(ARI } \\
\text { Acute } \\
\text { kidney } \\
\text { injury(AKI }\end{array}$ & $\begin{array}{l}\text { 1Fever, } \\
\text { Cough, } \\
\text { Fatigue, } \\
\text { Diarrhoea, } \\
\text { Myalgia, } \\
\text { Nausea, } \\
\text { Vomiting, } \\
\text { Polypnea, } \\
\text { Expecto- } \\
\text { ration, } \\
\text { Headache } \\
\text {, }\end{array}$ & Mortality \\
\hline
\end{tabular}




\begin{tabular}{|c|c|c|c|c|c|c|c|c|}
\hline $\begin{array}{l}\text { Author, } \\
\text { Year }\end{array}$ & Country & $\begin{array}{l}\text { Study } \\
\text { design }\end{array}$ & $\begin{array}{l}\text { Sample } \\
\text { size }(\mathrm{N})\end{array}$ & $\begin{array}{l}\text { Diabetes } \\
\text { diabetes }\end{array}$ & $\begin{array}{l}\text { Jon- } \\
\text { Age }\end{array}$ & $\begin{array}{l}\text { Comorbi } \\
\text { Compli- } \\
\text { cations }\end{array}$ & $\begin{array}{l}\text { ties/ } \\
\text { Symptoms }\end{array}$ & $\begin{array}{l}\text { Mortality, } \\
\text { Alive/recov }\end{array}$ \\
\hline $\begin{array}{l}\text { Zhang, } \\
\text { 2020a }\end{array}$ & China & \multicolumn{2}{|c|}{$\begin{array}{l}\text { Retrospective } 145 \\
\text { obser- } \\
\text { va- } \\
\text { tional } \\
\text { study }\end{array}$} & $61 / 84$ & $\begin{array}{l}\text { Mean: } \\
62.7\end{array}$ & $\begin{array}{l}\text { Hypertens } \\
\text { CVD, } \\
\text { Cere- } \\
\text { brovas- } \\
\text { cular } \\
\text { dis- } \\
\text { ease, } \\
\text { COPD, } \\
\text { CKD, } \\
\text { Thy- } \\
\text { roid } \\
\text { Can- } \\
\text { cer/Malig } \\
\text { Diges- } \\
\text { tive } \\
\text { system } \\
\text { disease }\end{array}$ & $\begin{array}{l}\text { Fever, } \\
\text { Cough, } \\
\text { Fa- } \\
\text { tigue, } \\
\text { Diar- } \\
\text { rhoea, } \\
\text { Nau- } \\
\text { sea, } \\
\text { Vomit- } \\
\text { ing, } \\
\text { Expec- } \\
\text { tora- } \\
\text { ncioss, } \\
\text { Chest } \\
\text { Pain, } \\
\text { Headache, } \\
\text { Anorexia, } \\
\text { Dysp- } \\
\text { noea, } \\
\text { Sore } \\
\text { throat, } \\
\text { Palpitation }\end{array}$ & Mortality \\
\hline $\begin{array}{l}\mathrm{Xu} \\
2020\end{array}$ & China & $\begin{array}{l}\text { Observa } \\
\text { study }\end{array}$ & 364 & $114 / 250$ & $\begin{array}{l}\text { Mean } \\
(\mathrm{IQR}): \\
65 \\
(55-73)\end{array}$ & - & - & Mortality \\
\hline $\begin{array}{l}\text { Shang, } \\
2020\end{array}$ & China & $\begin{array}{l}\text { Retrosp } \\
\text { cohort } \\
\text { study }\end{array}$ & e584 & $84 / 500$ & - & \multicolumn{2}{|c|}{$\begin{array}{ll}\text { Hypertension,Fever, } \\
\text { CVD, } & \text { Cough, } \\
\text { ARDS, } & \text { Fatigue, } \\
\text { COPD, } & \text { Diarrhoea, } \\
\text { CKD, } & \text { Nausea, } \\
\text { CLD, } & \text { Vomiting, } \\
\text { Can- } & \text { Myalgia, } \\
\text { cer/Malignandixsecto- } \\
\text { ACI, AKI, } & \text { ration, } \\
& \text { Chest } \\
& \text { Pain, } \\
& \text { Headache, } \\
& \text { Anorexia, } \\
& \text { Dyspnoea, } \\
& \text { Sore } \\
& \text { throat, } \\
& \text { Palpitation }\end{array}$} & $\begin{array}{l}\text { Mortality, } \\
\text { Alive/recover }\end{array}$ \\
\hline
\end{tabular}




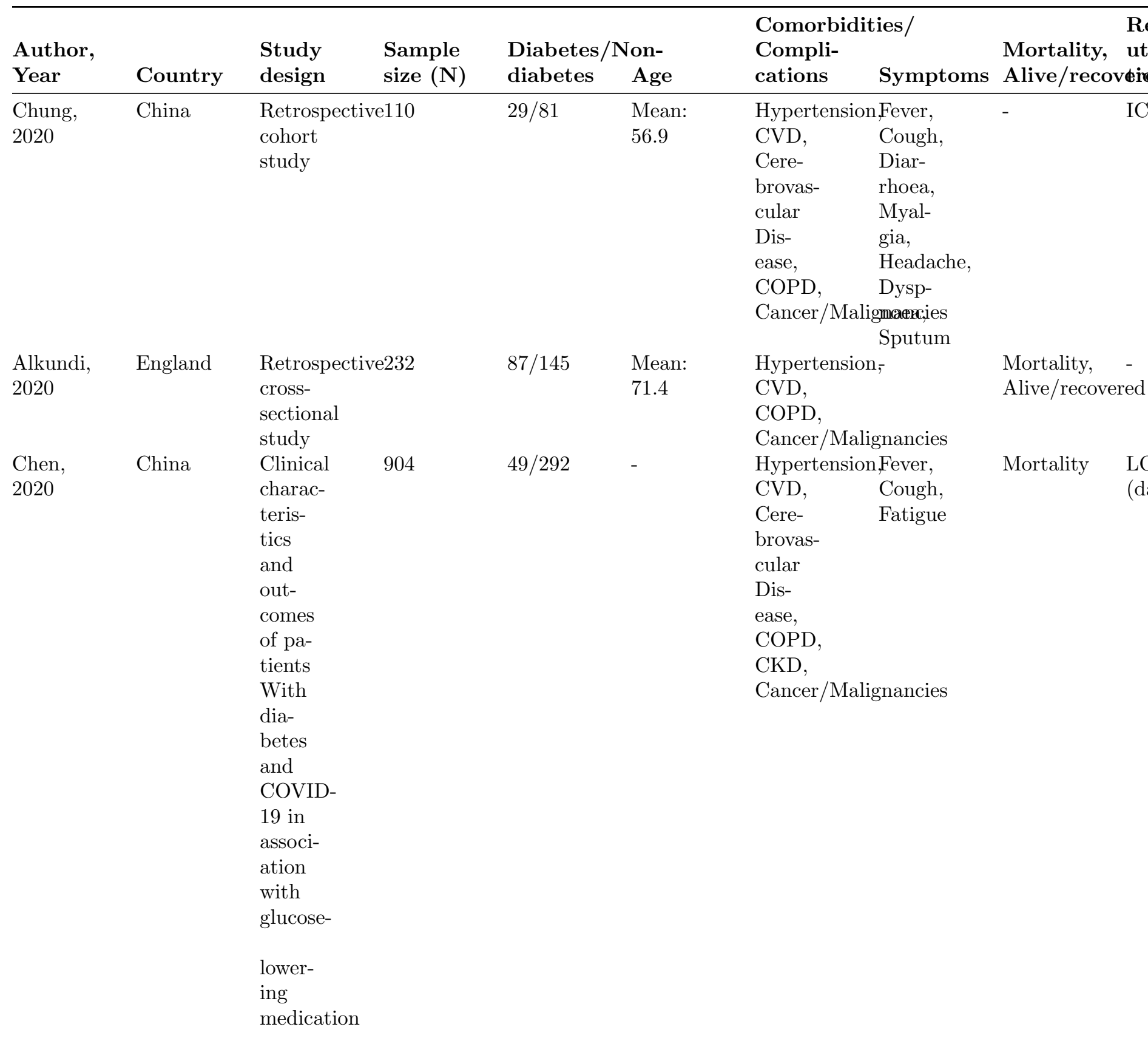




\begin{tabular}{|c|c|c|c|c|c|c|c|c|}
\hline $\begin{array}{l}\text { Author, } \\
\text { Year }\end{array}$ & Country & $\begin{array}{l}\text { Study } \\
\text { design }\end{array}$ & $\begin{array}{l}\text { Sample } \\
\text { size }(N)\end{array}$ & $\begin{array}{l}\text { Diabetes } \\
\text { diabetes }\end{array}$ & $\begin{array}{l}\text { Jon- } \\
\text { Age }\end{array}$ & $\begin{array}{l}\text { Comorb } \\
\text { Compli- } \\
\text { cations }\end{array}$ & $\begin{array}{l}\text { ties / } \\
\text { Symptoms }\end{array}$ & $\begin{array}{l}\text { Rortality, } \\
\text { Alive/recovei }\end{array}$ \\
\hline $\begin{array}{l}\text { Yan, } \\
2020\end{array}$ & China & $\begin{array}{l}\text { retrosp } \\
\text { obser- } \\
\text { va- } \\
\text { tional } \\
\text { study }\end{array}$ & 193 & $48 / 145$ & $\begin{array}{l}\text { Mean } \\
(\mathrm{IQR}): \\
64 \\
(49-73)\end{array}$ & $\begin{array}{l}\text { Hyperten } \\
\text { CVD, } \\
\text { Cere- } \\
\text { brovas- } \\
\text { cular } \\
\text { Dis- } \\
\text { ease, } \\
\text { COPD, } \\
\text { CKD, } \\
\text { CLD, }\end{array}$ & $\begin{array}{l}\text { 1Fever, } \\
\text { Cough, } \\
\text { Fa- } \\
\text { tigue, } \\
\text { Diar- } \\
\text { rhoea, } \\
\text { Nau- } \\
\text { sea, } \\
\text { Vomit- } \\
\text { ing, } \\
\text { Headache, } \\
\text { Anorexia, } \\
\text { Dyspnoea }\end{array}$ & Mortality \\
\hline $\begin{array}{l}\text { Bode, } \\
2020\end{array}$ & USA & $\begin{array}{l}\text { Retrosp } \\
\text { obser- } \\
\text { va- } \\
\text { tional } \\
\text { study }\end{array}$ & e1122 & $451 / 671$ & $\begin{array}{l}\text { Median } \\
(\mathrm{IQR}): \\
65 \\
(24-95)\end{array}$ & - & - & $\begin{array}{l}\text { Mortality, } L \\
\text { Alive/recovere }\end{array}$ \\
\hline $\begin{array}{l}\text { Wang, } \\
2020\end{array}$ & China & $\begin{array}{l}\text { Retrosp } \\
\text { study }\end{array}$ & e132 & $47 / 85$ & $\begin{array}{l}\text { Median } \\
(\mathrm{IQR}): \\
60 \\
(56-72)\end{array}$ & $\begin{array}{l}\text { Hyperten } \\
\text { CVD, } \\
\text { Cere- } \\
\text { brovas- } \\
\text { cular } \\
\text { Dis- } \\
\text { ease, } \\
\text { COPD, } \\
\text { CKD, } \\
\text { Thyroid }\end{array}$ & $\begin{array}{l}\text { 1Fever, } \\
\text { Fa- } \\
\text { tigue, } \\
\text { Diar- } \\
\text { rhoea, } \\
\text { Myal- } \\
\text { gia, } \\
\text { Short- } \\
\text { ness of } \\
\text { breathing }\end{array}$ & $\begin{array}{lr}\text { Mortality, } & \mathrm{T} \\
\text { Alive/recover } & \\
& \text { or } \\
& \text { to } \\
& \mathrm{m} \\
& (\mathrm{c}\end{array}$ \\
\hline
\end{tabular}




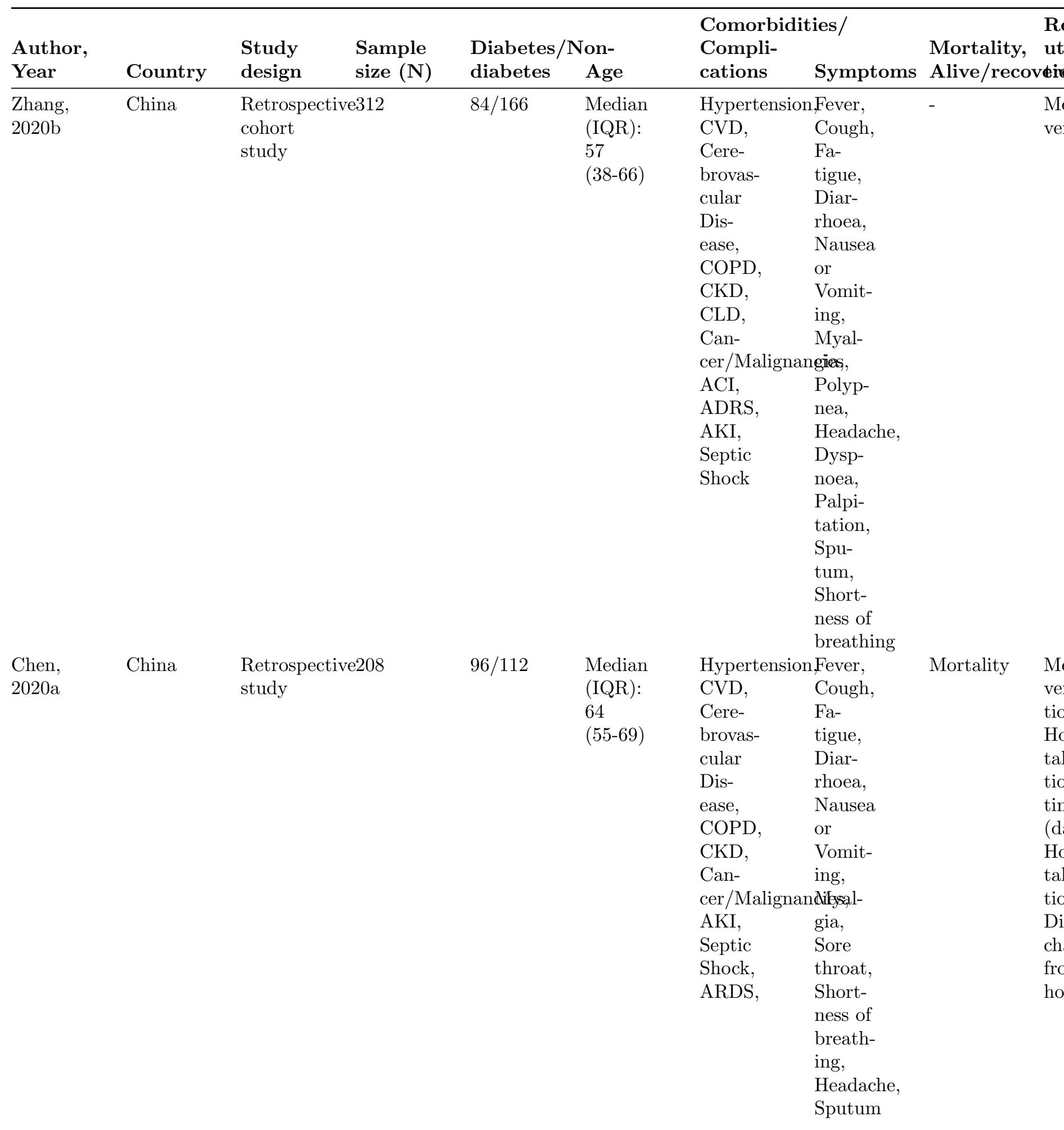




\begin{tabular}{|c|c|c|c|c|c|c|c|c|}
\hline $\begin{array}{l}\text { Author, } \\
\text { Year }\end{array}$ & Country & $\begin{array}{l}\text { Study } \\
\text { design }\end{array}$ & $\begin{array}{l}\text { Sample } \\
\text { size (N) }\end{array}$ & $\begin{array}{l}\text { Diabetes } \\
\text { diabetes }\end{array}$ & $\begin{array}{l}\text { Ton- } \\
\text { Age }\end{array}$ & $\begin{array}{l}\text { Comorb } \\
\text { Compli- } \\
\text { cations }\end{array}$ & $\begin{array}{l}\text { ies / } \\
\text { Symptoms }\end{array}$ & $\begin{array}{l}\text { Mortality, } \\
\text { Alive/recov }\end{array}$ \\
\hline $\begin{array}{l}\mathrm{Li} \\
2020\end{array}$ & 更 & $\begin{array}{l}\text { Retrosp } \\
\text { study }\end{array}$ & e199 & $76 / 123$ & $\begin{array}{l}\text { Median } \\
(\mathrm{IQR}): \\
63 \\
(50-75)\end{array}$ & - & $\begin{array}{l}\text { Fever, } \\
\text { Cough, } \\
\text { Anorexia, } \\
\text { Fa- } \\
\text { tigue, } \\
\text { Dysp- } \\
\text { noea, } \\
\text { Diar- } \\
\text { rhoea, } \\
\text { Nau- } \\
\text { sea, } \\
\text { Vomit- } \\
\text { ing, } \\
\text { Headache }\end{array}$ & $\begin{array}{l}\text { Mortality, } \\
\text { Alive/recover }\end{array}$ \\
\hline $\begin{array}{l}\text { Liu, } \\
2020\end{array}$ & China & $\begin{array}{l}\text { Retrosp } \\
\text { study }\end{array}$ & e934 & $139 / 795$ & $\begin{array}{l}\text { Mean: } \\
64.5\end{array}$ & $\begin{array}{l}\text { CVD, } \\
\text { Cere- } \\
\text { brovas- } \\
\text { cular } \\
\text { Dis- } \\
\text { ease, } \\
\text { COPD, } \\
\text { Diges- } \\
\text { tive } \\
\text { System } \\
\text { Disor- } \\
\text { der, } \\
\text { Cancer/M }\end{array}$ & $\begin{array}{l}\text { Fever } \\
\text { gnancies' }\end{array}$ & Mortality \\
\hline
\end{tabular}

Data presented as Median (IQR)

Abbreviation: IQR: Interquartile range; CVD:Cardiovascular disease; COPD: Chronic obstructive pulmonary disease; CKD: Chronic kidney disease; CLD: Chronic liver disease; ACI: Acute cardiac injury; ICU:Intensive care unit; LOS: Length of stay; AKI: Acute kidney injury

Table 2. Results summary from meta-analysis for symptoms

\begin{tabular}{lllll}
\hline Outcomes & Number of studies & Diabetic population & Diabetic population & Non diabetic populat \\
\hline & & Total & Events & Total \\
Fatigue & 9 & 608 & 277 & 1658 \\
Fever & 11 & 776 & 535 & 2534 \\
Headache & 7 & 457 & 46 & 906 \\
Myalgia & 6 & 403 & 71 & 1095 \\
Nausea and vomiting & 7 & 512 & 76 & 1325 \\
Anorexia & 4 & 269 & 92 & 852 \\
Cough & 10 & 637 & 449 & 1739 \\
Diaarhea & 9 & 588 & 112 & 1447 \\
Dyspnea & 6 & 382 & 214 & 1099 \\
Palipitation & 2 & 145 & 22 & 250
\end{tabular}




\begin{tabular}{lllll}
\hline Outcomes & Number of studies & Diabetic population & Diabetic population & Non diabetic populat \\
\hline Pharyngalgia & 2 & 147 & 12 & 695 \\
Shortness of breath & 2 & 143 & 73 & 153 \\
Polypnea & 2 & 147 & 44 & 361 \\
Sore throat & 2 & 157 & 15 & 196 \\
Sputum & 2 & 125 & 38 & 193 \\
Chest pain & 2 & 124 & 13 & 279 \\
Expectoration & 2 & 124 & 58 & 279 \\
\hline
\end{tabular}

$P<0.05$ considered significant

Abbreviation: OR: Odds ratio; CI: Confidence interval; $\mathbf{I}^{2:}$ Heterogeneity
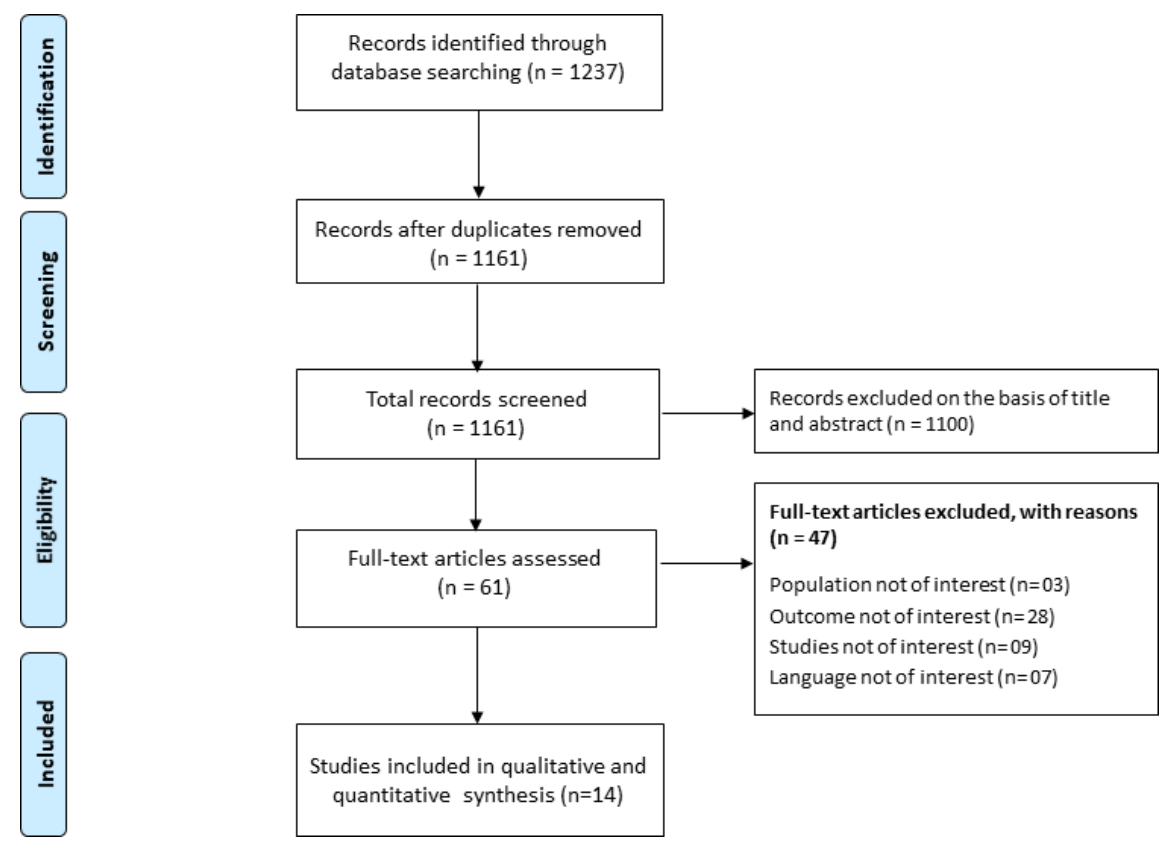

\section{Hosted file}

Figure 2. Forest plot for comorbidities and diabetes.pdf available at https://authorea.com/ users/404337/articles/515550-risk-factors-associated-with-diabetes-mellitus-in-covid-19infected-patients-a-meta-analytic-synthesis-of-observational-studies 


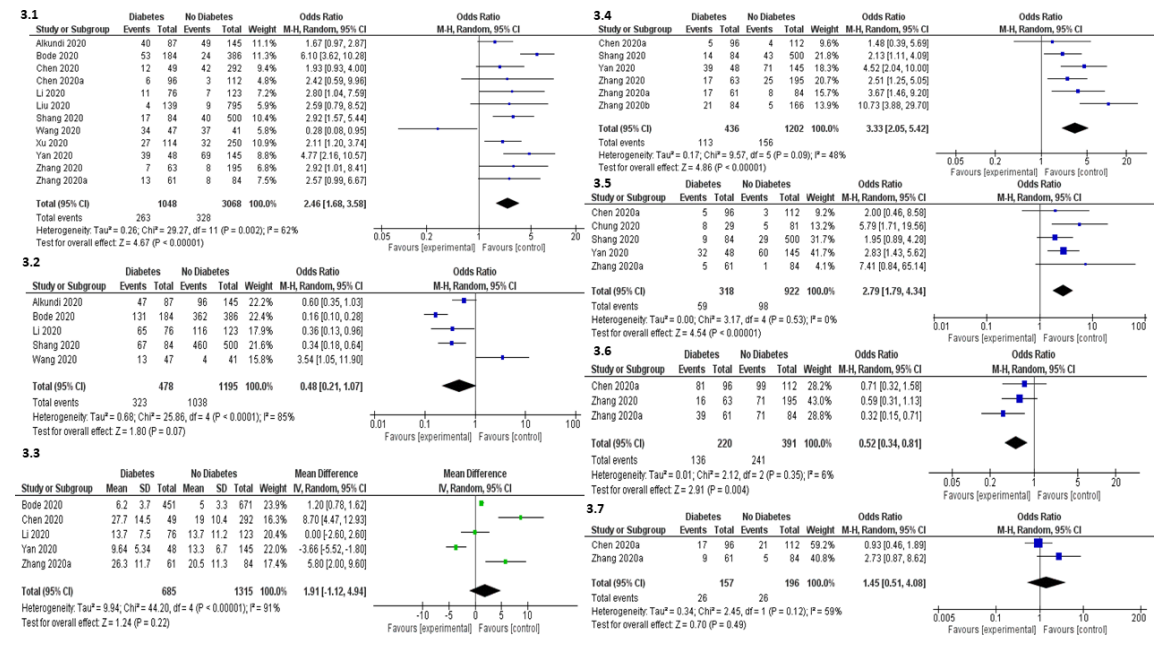

